\title{
Quality of life of patients after anterior cruciate ligament reconstruction using LARS synthetic graft and autogenous ST/GR graft
}

\section{Jakość życia pacjentów po rekonstrukcji więzadła krzyżowego przedniego z zastosowaniem przeszczepu syntetycznego LARS i przeszczepu autogennego ST/GR}

\author{
Jędrzej Płocki ${ }^{1,2}$, Ireneusz Kotela ${ }^{3,4}$, Agnieszka Bejer ${ }^{1,5}$, Dominik Pikuła ${ }^{1}$, Mirosław Probachta ${ }^{1,5}$, Andrzej Kotela ${ }^{3,6}$ \\ ${ }^{1}$ Department of Rehabilitation, Holy Family Specialist Hospital, Rudna Mała, Poland \\ Head of the Department: Bożena Sałata MD \\ ${ }^{2}$ Chair of Physiotherapy, Faculty of Medicine, University of Information Technology and Management with Seat, Rzeszow, Poland \\ Head of the Chair: Helena Bartyzel-Lewforowicz PhD \\ ${ }^{3}$ Department of Orthopaedics and Traumatology Clinic of Orthopaedics and Traumatology, Central Clinical Hospital of the Ministry \\ of Internal Affairs, Warsaw, Poland \\ Head of the Department: Prof. Ireneusz Kotela MD, PhD \\ ${ }^{4}$ Department of Rehabilitation in Disease of the Locomotor, Institute of Physiotherapy, Faculty of Health Sciences, Jan Kochanowski \\ University (JKU), Kielce, Poland \\ Head of the Department: Prof. Ireneusz Kotela MD, PhD \\ ${ }^{5}$ Department of Medicine, Institute of Physiotherapy, Faculty of Medicine, University of Rzeszow, Rzeszow, Poland \\ Head of the Department: Prof. Anna Wilmowska-Pietruszyska PhD \\ ${ }^{6}$ Department of Orthopaedics and Traumatology, $1^{\text {st }}$ Faculty of Medicine, Medical University of Warsaw, Warsaw, Poland \\ Head of the Department: Prof. Paweł Małdyk MD, PhD
}

Key words: anterior cruciate ligament injury, reconstruction, LARS method, quality of life.

Słowa kluczowe: uszkodzenie więzadła krzyżowego przedniego, rekonstrukcja, metoda LARS, jakość życia.

\begin{abstract}
Introduction: Injury to the anterior cruciate ligament (ACL) causes disorders in the functional capabilities of the limb, both in daily life and during attempts to return to full physical activity, and in a later period it contributes to the development of degenerative disease.

Aim of the research: Determination of the level of quality of life in patients after ACL reconstruction using the LARS synthetic ligament or autogenous ST/GR graft 4 years after surgery.

Material and methods: Into the study were qualified 96 patients who had undergone reconstruction due to injury to the anterior cruciate ligament. The patients were divided into two groups according to the type of material used for reconstruction. The study group included $44(45.8 \%)$ patients who were operated on using the LARS synthetic ligament. The control group comprised $52(54.2 \%)$ patients who were implanted with an autogenous graft from semitendinous or gracilis muscle. The study was conducted using the SF36v2 questionnaire for the assessment of quality of life.

Results: The patients expressed the most negative evaluations of quality of life in the domain of General Health (GH) $(\bar{x}=62.5$ scores $)$ and Mental Health $(\mathrm{MH})(\bar{x}=70.4$ scores $)$, whereas most positive evaluations concerned the domain related with role limitations - caused both by physical health (Role Pysical - RP) and emotional problems (Role Emotional - RE) $(\bar{x}>95$ scores). No statistically significant differences in the level of the quality of life were observed in the two selected groups; however, the evaluation of the quality of life in the area of social functioning and psychological health were slightly higher in the group of patients who had undergone surgery using the LARS method.

Conclusions: The quality of life of patients within the period of 4 years after ACL reconstruction procedure using the LARS method and autogenous graft was on a similar, high level.
\end{abstract}

\section{Streszczenie}

Wprowadzenie: Uszkodzenie więzadła krzyżowego przedniego (ACL) powoduje zaburzenia funkcji kończyny zarówno w życiu codziennym, jak i podczas prób powrotu do pełnej aktywności fizycznej, a w późniejszym okresie rozwój choroby zwyrodnieniowej. 
Cel pracy: Określenie poziomu jakości życia pacjentów po rekonstrukcji ACL z zastosowaniem więzadła syntetycznego LARS lub przeszczepu autogennego ST/GR.

Materiał i metody: Do badań zakwalifikowano 96 pacjentów, u których z powodu uszkodzenia ACL wykonano rekonstrukcję. Pacjenci zostali podzieleni na dwie grupy ze względu na rodzaj użytego do materiału. Grupę badaną stanowiły $44(45,8 \%)$ osoby operowane z wykorzystaniem syntetycznego więzadła LARS. W grupie kontrolnej były $52(54,2 \%)$ osoby, u których wykonano autogenny przeszczep z mięśnia półścięgnistego lub smukłego. W badaniach zastosowano kwestionariusz SF36v2 służący do oceny jakości życia.

Wyniki: Najgorzej pacjenci oceniali jakość życia w dziedzinie zdrowie ogólne (General Health - GH) $(\bar{x}=62,5$ pkt) oraz poczucie zdrowia psychicznego (Mental Health - MH) $(\bar{x}=70,4 \mathrm{pkt}$ ), a najlepiej pod względem ograniczeń funkcjonowania - zarówno z powodu problemów fizycznych (Role Physical - RP), jak i emocjonalnych (Role Emotional - RE) (> 95 pkt).

Wnioski: Jakość życia pacjentów w ciagu 4 lat od zabiegu rekonstrukcji ACL metodą LARS i przeszczepu autogennego utrzymuje się na zbliżonym, wysokim poziomie.

\section{Introduction}

In recent years, injuries to the anterior cruciate ligament (ACL) have become a real epidemic. The injury most often concerns young, physically active individuals aged 15-25 years [1]. As many as 70\% of ACL injuries are non-contact injuries, which most frequently occur during a sudden change of running direction or landing after a jump [2, 3]. The consequence of damage to the ligamentous apparatus of the knee joint is its instability. It causes disorders of the functional capability of the limb, both in daily life and during attempts to return to full physical activity, and in the later period it contributes to the development of degenerative disease [4]. Instability of the knee joint requires surgical treatment. For many years, arthroscopy has been the method of choice applied for treatment of ruptures of the ACL [5]. The material most often used for the reconstruction of the anterior cruciate ligament are autologous tendons of the semitendinous or gracilis muscle. Synthetic materials are considerably more rarely applied for ACL reconstruction, although their use has been described since the 1970s [6]. At present, in some orthopaedic wards in Poland, ACL reconstructions are performed using the LARS synthetic ligament. Due to the mechanical and structural characteristics of the ligament, this method allows considerable acceleration of the return to normal function of the knee joint and, consequently, the return to physical and occupational activity [7].

It is commonly known that the disease, to varying degrees, disturbs the functioning of people, thus having an effect on quality of life in many dimensions and in various periods of time. Since the 1990s, the concept of quality of life has been associated primarily with the state of health. However, many researchers considered that quality of life is not only a state of health, but also of social position or social situation [8]. In the case of injuries to the ACL and evaluation of the quality of life of patients within 4 years of surgery, it seems that the quality of life may be assessed according to one of the sociologic definitions, which states that 'the quality of life covers those needs of an individual that are considered by this individual as most important for their own life, and an individual's opinions concern- ing the level of satisfaction of these needs' [9]. The goal of each patient who has undergone the reconstruction of damaged ACL is the return to the activity from before the injury [10]. If, and in what dimension this is successful, may affect the evaluation of the quality of life of the individual. Correctly planned rehabilitation is an indispensable element of treatment of patients after ACL reconstruction [11]. It is aimed at the restoration of the lost function of the knee joint, and consequently, improvement of the quality of life of patients.

\section{Aim of the research}

The objective of the study was the determination of the level of quality of life of patients after ACL reconstruction using the LARS synthetic ligament or autogenous ST/GR graft within 4 years after the surgery.

\section{Material and methods}

Into the study were qualified 96 patients, in whom, during the period 2010-2012, reconstruction was performed in the Holy Family Specialist Hospital in Rudna Mała near Rzeszow, due to injury to the anterior cruciate ligament. The mean period between the reconstruction of the ligament and the examination was 4 years.

From the study were excluded patients aged over 50 years, those who had undergone the reconstruction of more than one ligament, with a currently present injury in one of the joints in the healthy or operated limb, and patients in whom revision reconstruction had been performed.

As a criterion neutral for the study were considered concomitant surgeries of suturing, or removal of the fragments of the meniscus performed during the primary ACL reconstruction.

The patients were divided into two groups according to the type of material used for the reconstruction. The study group consisted of 44 (45.8\%) patients operated on with the use of the LARS synthetic ligament. The control group included 52 (54.2\%) patients who had been transplanted with an autogenous graft from the semitendinous or gracilis muscle.

In the study, the results were analysed of patients aged $27-50$ years. The patients who had undergone an 
autogenous graft were approximately 4 years younger, on average $(\bar{x}=34.6$; $\mathrm{Me}=33.5$; $\mathrm{SD}=7.3)$, than those operated on using the LARS method $(\bar{x}=38.8$; $\mathrm{Me}=39.0 ; \mathrm{SD}=8.0$ ).

In the population examined, the number of males was considerably higher than that of females -76 and 20 , respectively. The selection of such a group depended on a limited number of patients who had undergone surgery using the LARS method. Both groups were comparable with respect to gender. In the LARS group, there were 37 (84.1\%) males, and 7 (15.9\%) females, whereas in the group with autogenous graft there were 39 (75.0\%) males and $13(25.0 \%)$ females.

The presented study was conducted by means of a diagnostic survey, and the research instrument was the SF36v2 questionnaire for assessment of quality of life. The questionnaire contains 36 items grouped into eight domains: physical functioning, social functioning, role limitations due to physical health; role limitations due to emotional problems, mental health, vitality, bodily pain, and general health perceptions. In each domain, the possible result was within the range $0-100$; the lower the number of scores, the worse the quality of life.

\section{Statistical analysis}

Statistical analyses were performed using descriptive statistics and Mann-Whitney $U$ test. A $p$-value $<0.05$ was considered statistically significant.

\section{Results}

Based on information collected by means of the SF-36v2 questionnaire, the quality of life of patients after surgery was assessed. Table 1 presents descriptive statistics, characterising the distribution of quality of life measures in the total population examined.
The patients expressed the most negative evaluations in the domain of General Health $(\mathrm{GH})(\bar{x}=$ 62.5 scores) and perception of Mental Health (MH) $(\bar{x}=70.4$ scores). The most positive evaluations concerned the domain of role limitations due to physical health (Role Physical - RP) and role limitations due to emotional problems (Role Emotional - RE) $(\bar{x}>95$ scores) (Table 1).

The quality of life of patients was compared according to the type of surgery performed. No statistically significant differences were observed in the level of measurements of the quality of life. The assessment of the quality of life in the area of social functioning and mental health were slightly higher in the group of patients who were operated on using the LARS method. The differences were close to statistically significant (the value of the test probability $p$ was lower than 0.10) (Table 2).

The type of rehabilitation undertaken in patients who had undergone ACL reconstruction using the semitendinosus-gracilis autograft (ST-GR) was significant for the evaluation of the quality of life. Patients who, apart from physical procedures, had undergone procedures within the scope of kinesiotherapy obtained significantly higher results in the assessment of the quality of life with respect to the domain of physical functioning, perception of general health, as well as the summary index of physical health (Table 3).

In the group of patients who had undergone surgery using the LARS method, it was observed that the type of rehabilitation did not determine the result of the study in any of the domains of the quality of life within the period of 4 years after surgery (Table 4 ).

\section{Discussion}

In the literature there are few reports concerning the quality of life of patients who had undergone re-

Table 1. Results in individual domains of quality of life in the total population examined

\begin{tabular}{|lccccccc|}
\hline Domains of quality of life (SF-36v2) & $\bar{x}$ & Me & SD & $\mathbf{c}_{25}$ & $\mathbf{c}_{75}$ & Min. & Max. \\
PF - Physical Functioning & 93.5 & 95.0 & 12.3 & 95.0 & 100.0 & 15.0 & 100.0 \\
$\begin{array}{l}\text { RP - Role-Physical } \\
\text { role limitations due to physical health }\end{array}$ & 95.6 & 100.0 & 14.0 & 100.0 & 100.0 & 25.0 & 100.0 \\
$\begin{array}{l}\text { BP - Bodily Pain } \\
\text { GH - General Health }\end{array}$ & 90.3 & 100.0 & 14.0 & 83.8 & 100.0 & 45.0 & 100.0 \\
general health perceptions & 64.2 & 62.5 & 15.0 & 50.0 & 75.0 & 25.0 & 100.0 \\
$\begin{array}{l}\text { RE - Role-Emotional } \\
\text { role limitations due to emotional problems }\end{array}$ & 95.1 & 100.0 & 16.7 & 100.0 & 100.0 & 0.0 & 100.0 \\
VT - Vitality & 72.1 & 75.0 & 16.4 & 56.3 & 87.5 & 25.0 & 100.0 \\
SF - Social Functioning & 89.7 & 100.0 & 14.5 & 87.5 & 100.0 & 37.5 & 100.0 \\
MH - Mental Health & 70.4 & 71.1 & 13.2 & 60.0 & 80.0 & 40.0 & 100.0 \\
PCS - Physical Component Summary & 90.3 & 93.3 & 11.1 & 89.0 & 95.8 & 25.8 & 100.0 \\
MCS - Mental Component Summary & 77.1 & 79.4 & 11.3 & 67.9 & 86.4 & 51.9 & 98.9 \\
\hline
\end{tabular}


Table 2. Quality of life in individual domains according to the type of surgery

\begin{tabular}{|c|c|c|c|c|c|c|c|}
\hline \multirow[t]{3}{*}{ Domains of quality of life (SF-36v2) } & \multicolumn{6}{|c|}{ Group } & \multirow[t]{3}{*}{$P$-value } \\
\hline & \multicolumn{3}{|c|}{ Autogenous graft } & \multicolumn{3}{|c|}{ LARS method } & \\
\hline & $\bar{x}$ & $\mathrm{Me}$ & SD & $\bar{x}$ & $\mathrm{Me}$ & SD & \\
\hline PF - Physical Functioning & 91.1 & 95.0 & 15.8 & 96.4 & 97.5 & 4.6 & 0.2666 \\
\hline $\begin{array}{l}\mathrm{RP} \text { - Role-Physical } \\
\text { role limitations due to physical health }\end{array}$ & 93.3 & 100.0 & 17.9 & 98.3 & 100.0 & 6.4 & 0.5361 \\
\hline BP - Bodily Pain & 88.3 & 90.0 & 15.2 & 92.6 & 100.0 & 12.2 & 0.1293 \\
\hline $\begin{array}{l}\text { GH - General Health } \\
\text { general health perceptions }\end{array}$ & 63.0 & 62.5 & 16.6 & 65.6 & 62.5 & 13.0 & 0.2928 \\
\hline $\begin{array}{l}\mathrm{RE}-\text { Role-Emotional } \\
\text { role limitations due to emotional problems }\end{array}$ & 92.9 & 100.0 & 20.2 & 97.7 & 100.0 & 11.1 & 0.4572 \\
\hline VT - Vitality & 70.4 & 75.0 & 16.7 & 74.1 & 75.0 & 15.9 & 0.3135 \\
\hline SF - Social Functioning & 87.0 & 87.5 & 16.4 & 92.9 & 100.0 & 11.2 & 0.0847 \\
\hline MH - Mental Health & 68.2 & 70.0 & 12.2 & 72.9 & 76.7 & 13.9 & 0.1051 \\
\hline PCS - Physical Component Summary & 88.1 & 93.2 & 14.3 & 93.0 & 94.4 & 4.4 & 0.2828 \\
\hline MCS - Mental Component Summary & 74.9 & 75.6 & 11.6 & 79.6 & 81.9 & 10.6 & 0.0524 \\
\hline
\end{tabular}

Table 3. Quality of life in individual domains according to the type of rehabilitation undertaken, in the group of patients after autogenous graft

\begin{tabular}{|c|c|c|c|c|c|c|c|}
\hline \multirow[t]{3}{*}{ Domains of quality of life (SF-36v2) } & \multicolumn{6}{|c|}{ Type of rehabilitation undertaken } & \multirow[t]{3}{*}{$P$-value } \\
\hline & \multicolumn{3}{|c|}{ Physiotherapy $(n=7)$} & \multicolumn{3}{|c|}{$\begin{array}{c}\text { Kinesiotherapy + } \\
\text { physiotherapy }(n=42)\end{array}$} & \\
\hline & $\bar{x}$ & Me & SD & $\bar{x}$ & Me & SD & \\
\hline PF - Physical Functioning & 80.7 & 85.0 & 20.7 & 92.7 & 97.5 & 14.7 & $0.0336^{\star}$ \\
\hline $\begin{array}{l}\mathrm{RP}-\text { Role-Physical } \\
\text { role limitations due to physical health }\end{array}$ & 85.7 & 100.0 & 24.4 & 94.0 & 100.0 & 17.3 & 0.4922 \\
\hline BP - Bodily Pain & 83.9 & 90.0 & 16.6 & 90.1 & 100.0 & 14.1 & 0.3041 \\
\hline $\begin{array}{l}\text { GH - General Health } \\
\text { general health perceptions }\end{array}$ & 50.0 & 50.0 & 7.2 & 64.3 & 62.5 & 16.2 & $0.0133^{*}$ \\
\hline $\begin{array}{l}\mathrm{RE}-\text { Role-Emotional } \\
\text { role limitations due to emotional problems }\end{array}$ & 90.5 & 100.0 & 25.2 & 93.7 & 100.0 & 19.8 & 0.8999 \\
\hline VT - Vitality & 70.5 & 81.3 & 17.9 & 71.0 & 71.9 & 15.6 & 0.9443 \\
\hline SF - Social Functioning & 85.7 & 87.5 & 15.2 & 87.5 & 87.5 & 16.8 & 0.6646 \\
\hline MH - Mental Health & 64.8 & 66.7 & 9.6 & 68.3 & 71.1 & 12.6 & 0.3761 \\
\hline PCS - Physical Component Summary & 78.8 & 85.0 & 18.7 & 89.6 & 93.9 & 13.3 & $0.0265^{*}$ \\
\hline MCS - Mental Component Summary & 72.7 & 78.9 & 12.2 & 75.3 & 75.1 & 11.2 & 0.6046 \\
\hline
\end{tabular}

construction of ACL rupture. Barenius et al., during an 8-year period of observation of patients after autogenous graft, presented the mean result in the SF36 scale of 75 scores (the respondents obtained the lowest result with respect to the domain of vitality 67 scores). The researchers considered that the accompanying damage to the meniscus results in a more negative assessment of the quality of life in patients in whom the reconstruction of ACL rupture was per- formed [12]. These results are similar to the results of our own study (mean result - 83.1 scores), despite a considerable difference in time when they were performed. Busija et al., in a study conducted 2 years after the reconstruction of ACL using ST/GR graft, presented the results obtained by means of the SF-36 questionnaire with a mean level of 83.4 scores. This result is nearly identical to that obtained in the presented study. According to the above-mentioned researchers, 
Table 4. Quality of life in individual domains according to the type of rehabilitation undertaken, in the group of patients treated using the LARS method

\begin{tabular}{|c|c|c|c|c|c|c|c|}
\hline \multirow[t]{3}{*}{ Quality of life measures } & \multicolumn{6}{|c|}{ Type of rehabilitation undertaken } & \multirow[t]{3}{*}{$P$-value } \\
\hline & \multicolumn{3}{|c|}{ Physiotherapy $(n=6)$} & \multicolumn{3}{|c|}{$\begin{array}{c}\text { Kinesiotherapy }+ \\
\text { physiotherapy }(n=38)\end{array}$} & \\
\hline & $\bar{x}$ & Me & SD & $\bar{x}$ & Me & SD & \\
\hline PF - Physical Functioning & 97.5 & 97.5 & 2.7 & 96.2 & 97.5 & 4.9 & 0.8808 \\
\hline $\begin{array}{l}\mathrm{RP} \text { - Role-Physical } \\
\text { role limitations due to physical health }\end{array}$ & 100.0 & 100.0 & 0.0 & 98.0 & 100.0 & 6.8 & 0.7769 \\
\hline BP - Bodily Pain & 90.8 & 100.0 & 14.5 & 92.9 & 100.0 & 11.9 & 0.8546 \\
\hline GH - General Health & 66.7 & 62.5 & 17.1 & 65.5 & 62.5 & 12.5 & 0.9867 \\
\hline $\begin{array}{l}\mathrm{RE}-\text { Role-Emotional } \\
\text { role limitations due to emotional problems }\end{array}$ & 88.9 & 100.0 & 27.2 & 99.1 & 100.0 & 5.4 & 0.5816 \\
\hline VT - Vitality & 83.3 & 84.4 & 13.5 & 72.7 & 75.0 & 15.9 & 0.1398 \\
\hline SF - Social Functioning & 95.8 & 100.0 & 6.5 & 92.4 & 100.0 & 11.8 & 0.7769 \\
\hline MH - Mental Health & 77.4 & 75.6 & 14.6 & 72.2 & 76.7 & 13.9 & 0.4719 \\
\hline PCS - Physical Component Summary & 93.9 & 92.6 & 3.9 & 92.8 & 94.4 & 4.5 & 0.7514 \\
\hline MCS - Mental Component Summary & 82.7 & 82.9 & 12.1 & 79.1 & 81.9 & 10.5 & 0.5144 \\
\hline
\end{tabular}

the patients expressed the most negative evaluations with respect to their own vitality - on the level of 71 scores, and pain -75.2 scores [13].

Månsson et al., using the SF-36 questionnaire, examined 78 patients in Sweden, 2-7 years after reconstruction using the ST/GR graft. Compared to the Swedish patients operated on using the ST/GR graft, patients from Poland function worse in the domain of perception of mental health (MH ( $\bar{x}=68.2 \mathrm{vs} .82 .2)$, in the sphere of social functioning (SF $\bar{x}=87.0$ vs. 91.9), and general health $(\mathrm{GH}(\bar{x}=63.0$ vs. 82.2$)$. In the remaining domains of quality of life the patients in our own study obtained better results. In addition, Swedish researchers compared the results obtained using the SF-36 questionnaire from patients who had undergone surgery using the ST/GR graft, and those operated on using the patellar tendon graft - 331 patients. They did not find any differences between groups in any of the domains [14]. Gao et al., while conducting a study in China among 156 patients, showed that 127 of them $(81 \%)$ had a feeling of full satisfaction with life after surgery performed using the LARS method, while only 4 (3\%) patients were very dissatisfied [15]. Falconer et al. assessed the quality of life of patients 2 years after the ACL reconstruction with the double-bundle technique - ST/GR graft - control group (27 patients), and using the double-bundle technique - ST/GR graft and LARS ligament - LARS group (61 patients). The quality of life was investigated by means of the ACL-QOL questionnaire, and no significant differences were found between groups: $(\bar{x}=80.00$ (control group) and $\bar{x}=80.16$ (LARS group)) [16]. Núñez et al. compared the quality of life of patients 2 years after ACL reconstruction with the single-bundle technique (23 patients) and using the double-bundle technique (29 patients). The results obtained are comparable; however, the double-bundle technique is more expensive [17]. In the presented study, the quality of life of patients was compared according to the type of graft - autogenous ST/GR graft vs. LARS synthetic ligament. No statistically significant differences were observed in the level of patients' quality of life. However, the assessment in the domain of social functioning and mental health was slightly higher, and the values were close to the threshold of statistical significance in the group of patients who had undergone surgery using the LARS method. At the same time, this method is more costly than autogenous graft.

Machotka et al. performed a review of literature concerning the results obtained after ACL reconstruction using the LARS method. From among 20 articles published during 2000-2010 in eight databases, only four satisfied the criteria of enrolment into the analysis. A high level of patient satisfaction with life after the surgery was the only consistent result published in the analysed studies. However, the conclusion drawn from literature review is alarming because there is a lack of verified standards for conducting thorough rehabilitation of patients with the LARS ligament [18]. A study carried out by Jarosz et al., based on the results obtained from 201 patients after the ACL reconstruction with autogenous graft, and who received rehabilitation within the period of 6 months after the surgery, found that an improvement in the mental, physical, and social sphere of quality of life depended on the improvement of the 
results of orthopaedic examination concerning stability and the range of mobility in the knee joint [19]. In the presented study, the patients who had undergone ACL using ST/GR graft and subsequently received complex rehabilitation, including both individually adjusted kinesiotherapy as well as physiotherapy, obtained significantly better results in the domains of physical functioning, perception of general health, and summary index of physical health. Nevertheless, no differences were observed in the perceived quality of life in patients in the LARS group, according to the type of rehabilitation applied.

Assessment of quality of life should constitute an integral element of evaluation of the state of health of patients after ACL reconstruction, irrespective of the type of graft and method applied. Analysis of the effect of injury and reconstruction surgery on individual domains of life may help to establish the direction of therapeutic management. The present socio-economic situation and constantly growing health need of society indicate an improvement of the quality of life as the basic dimension of the effectiveness of therapy.

\section{Conclusions}

The quality of life of patients within four years after ACL reconstruction surgery using the LARS method and autogenous graft is on a similar, high level. The application of complex rehabilitation in the form of the method of kinesiotherapy combined with physiotherapeutic procedures results in an improvement of the quality of life of patients treated using the autogenous graft. In patients in whom the LARS was applied, no differences in the evaluations of the quality of life were observed according to the type of rehabilitation undertaken.

\section{Conflict of interest}

The authors declare no conflict of interest.

\section{References}

1. Murray M, Vavken P, Fleming B. The ACL Handbook: Knee Biology, Mechanics and Treatment. Springer Science and Buisiness Media, New York 2013; 3-17.

2. Stolarczyk A, Kalińska J, Nagraba $€$, Mitek T, Kołodziejski P. Postępowanie w uszkodzeniach więzadła krzyżowego przedniego. Artroskopia i Chirurgia Stawów 2007; 3: $18-29$.

3. Boden BP, Dean GS, Feagin JA Jr, Garrett WE Jr. Mechanisms of anterior cruciate ligament injury. Orthopedics 2000; 23: 573-8

4. Culvenor AG, Lai CH, Gabbe BJ, Makdissi M, Collins NJ, Vicenzino B, Morris HG, Crossley KM. Patellofemoral osteoarthritis is prevalent and associated with worse symptoms and function after hamstring tendon autograft ACL reconstruction. Br J Sports Med 2014; 48: 435-9.

5. Jędrysik M, Noga H, Żerebiec J. Rekonstrukcja więzadła krzyżowego przedniego z użyciem pasma centralnego więzadła rzepki. Acta Clinica 2002; 2: 26-32.
6. Legnani C, Ventura A, Terzaghi C, Borgo E, Albisetti W. Anterior cruciate ligament reconstruction with synthetic grafts. A review of literature. Int Orthop 2010; 34: 465-71.

7. Dericks G. Ligament advanced reinforcement system anterior cruciate ligament reconstruction. Oper Tech Sports Med 1995; 3: 187-205.

8. Chrobak M. Ocena jakości życia zależnej od stanu zdrowia. Probl Pielęgn 2009; 17: 123-7.

9. Jankowska E. Pojęcie i narzędzia pomiaru jakości życia. Toruńskie Studia Międzynarodowe 2011; 1: 33-9.

10. Kyritsis P, Witvrouw E. Return to sport after anterior cruciate ligament reconstruction: a literature review. J Nov Physiother 2014; 4: 4-10.

11. Baltaci G, Yilmaz G, Atay AO. The outcomes of anterior cruciate ligament reconstructed and rehabilitated knees versus healthy knees: a functional comparison. Acta Orthop Traumatol Turc 2012; 46: 186-95.

12. Barenius B, Nordlander M, Ponzer S, Tidermark J, Eriksson K. Quality of life and clinical outcome after anterior cruciate ligament reconstruction using patellar tendon graft or quadrupled semitendinosus graft an 8-year follow-up of a randomized controlled trial. Am J Sports Med 2010; 38: 1533-41.

13. Busija L, Osborne RH, Nilsdotter A, Buchbinder R, Roos EM. Magnitude and meaningfulness of change in SF-36 scores in four types of orthopedic surgery. Health Qual Life Outcomes 2008; 6: 55.

14. Månsson $\mathrm{O}$, Kartus J, Sernert N. Health-related quality of life after anterior cruciate ligament reconstruction. Knee Surg Sports Traumatol Arthrosc 2011; 19: 479-87.

15. Gao K, Chen S, Wang L, Zhang W, Kang Y, Dong Q, Zhou $\mathrm{H}$, Li L. Anterior cruciate ligament reconstruction with LARS artificial ligament: a multicenter study with 3- to 5-year follow-up. J Arthrosc Related Surg 2010; 26: 515-23.

16. Falconer T, Dabirrahmani D, Tusak L, et al. Comparison of hamstring and LARS hamstring augmentation double bundle ACL reconstruction - minimum 2 year follow-up. Available at: http://www.revolution-surgical.com/img/LARS/ knee/Falconer.pdf

17. Falconer T, Dabirrahmani D, Tusak L, Pollock J, Breidahl B, Annea P. Comparison of hamstring and LARS hamstring augmentation double bundle ACL reconstruction - minimum 2 year follow-up. Available at: http://www.revolution-surgical.com/img/LARS/ knee/Falconer.pdf

18. Machotka Z, Scarborough I, Duncan W, Kumar S, Perraton L. Anterior cruciate ligament repair with LARS. Sports Med Arthrosc Rehabil Ther Technol 2010; 2: 29-39.

19. Jarosz A, Dubaj W, Hładki W, Kruk SM. Assessment of the influence of the results of orthopedic examination on the quality of life in people undergoing reconstruction of the anterior cruciate ligemant of a knee and post-surgery rehabilitation. J Orthop Trauma Surg Rel Res 2013; 3: 33-41.

\section{Address for correspondence:}

\section{Jędrzej Płocki}

Department of Rehabilitation

Holy Family Specialist Hospital

Rudna Mała 600, 36-060 Głogów Młp., Poland

Phone: +48 781529464

E-mail: jplocki@gazeta.pl 